\title{
Dimensions of eWOM Credibility on the Online Purchasing Activities among Consumers Through Social Media
}

\author{
NOR AMIRA BAHARUDDIN \\ MOHAMMAD YAACOB \\ Universiti Teknologi MARA
}

\begin{abstract}
Word of mouth (WOM) communication has become a thoughtful information-sharing medium which can affect consumers' buying decisions and attitudes in the direction of product categorizations and brands. Conventional word of mouth (WOM) is an outdated method for sharing thoughts and has existed as far back as individuals traded data which now evolved to the new form of word of mouth which is the electronic word of mouth (eWOM). This study attempts to analyse the dimensions of eWOM credibility on online purchasing activities among consumers through social media. This study employs a quantitative method as the paradigm of methodology in gathering the data for this research. The questionnaires were distributed to 260 respondents. The result of this study has been analysed well as aligned with the research questions as well as the research objectives. The analysis revealed that all three major dimensions which are quality, rating and recommendation consistency had significantly underpinned the eWOM credibility on the online purchasing activities among consumers through social media and a new measurement model also had been developed. The relationship between the dimensions and the differences in the dimensions between consumers of different age and gender were also being analysed in this study where each condition showed dissimilar but accurate results. All the research questions had been thoroughly answered and the research objectives of this research had achieved as well. It is hoped that this study may contribute to the related field in the future.
\end{abstract}

Keywords: Word of mouth, electronic word of mouth, credibility, online purchasing, social media.

\section{INTRODUCTION}

Word of mouth (WOM) communication has become a thoughtful information-sharing medium which can affect consumers' buying decisions and attitudes in the direction of product categorizations and brands. Consumer behaviour is frequently affected with numerous kinds of advertising, nevertheless, the word of mouth comprehends a tougher influence than the contrary variations, for example, individual merchandising, printed as well as radio advertisements (Engel, Blackwell, \& Kegerreis, 1969). In addition, WOM is communication amongst consumers, which made of commentaries interconnected to products and services (Arndt, 1967). Generally, the standard nature of attaining info that we have a propensity to known as the advertising starts to be overwhelmed in term of its effectualness owing to trustworthiness complications (Trusov, Bucklin, \& Pauwels, 2009). The WOM is also becoming an influential instrument in the contemporary day environment, either having tremendous potential to create a brand or to ruin a brand. The perceived value needs to be considered in the process of decision making of consumers in purchasing products or services (Hoe, Dastane, \& Selvaraj, 2018). In the modern era, the improvement of social media has conveyed one newer angle to electronic word of mouth 
(eWOM) through permitting consumers to express with their recent structures or the existing networks. It has been discovered that WOM has noteworthy effects on the purchase intentions of customers (Engel, Blackwell, \& Kegerreis, 1969). Consumers in the area are beleaguered by mass media plus they alter the way of thinking of the consumers over needs, emotions, demands and wants (Mirabi, Akbariyeh, \& Tahmasebifard, 2015). And as time passed by, online reviews composed by the consumers similarly increased and come about by that, the marketers have additionally begun to draw in with internet-based life through their official accounts on the social media or websites. Consequently, it has been deliberated as an open door by them to interact with present or potential consumers.

\section{Research Questions}

a. How do the dimensions (quality, rating and recommendation consistency) significantly underpinning the electronic word of mouth (eWOM) credibility on the online purchasing activities among consumers through social media?

b. What is the relationship between the dimensions of electronic word of mouth (eWOM) credibility on the online purchasing activities among consumers through social media are related to each other?

c. How the dimensions of electronic word of mouth (eWOM) credibility on the online purchasing activities among consumers through social media are different between male and female, and between the age categories?

\section{Research Objectives}

a. To explore the dimensions of electronic word of mouth (EWOM) credibility on the online purchasing activities among consumers through social media.

b. To measure the relationship between the dimensions of electronic word of mouth (eWOM) credibility on the online purchasing activities among consumers through social media are related to each other.

c. To determine the differences in the dimensions of electronic word of mouth (eWOM) credibility on the online purchasing activities among consumers through social media between consumers of different age and gender.

\section{LITERATURE REVIEW}

A significant beginning period in the data influence procedure is the person's judgment of the validity of data, which decides how much the collector gains from and embraces the data. Along these lines, if individuals trust that the data received is valid, they will have more certainty to receive and trust the data of eWOM and use it to settle on the buy choice. There are a couple of measurements of eWOM validity on the internet acquiring exercises among purchasers through online networking, for example, quality, rating, recommendation consistency, content as well as volume however just three of the measurements will be additionally talked about in this exploration. 
Important Concepts (Dimensions of eWOM)

\section{a. Quality}

Studies show that eWOM credibility is pretentious by the quality of information (Tsao \& Hsieh, 2012). Nature of data incorporates different segments, for example, significance, practicality, exactness, and thoroughness. A brilliant eWOM gives purchasers more critical thinking proof, which can enable them to survey the believability of the review that they read. A study conducted by (Tsao \& Hsieh, 2012) found that eWOM with high quality will positively influence eWOM credibility.

\section{b. Rating}

Recommendation rating denotes to the general rating given by others for the eWOM communication (Cheung, Luo, Sia, \& Chen, 2009). Individuals can give a high or low score to the message as indicated by their impression of it. Accordingly, an accumulated rating is a normal portrayal of how past consumers assessed and saw this proposal. Studies have discovered that this proposal rating score impacts the way individuals see message validity (Cheung, Luo, Sia, \& Chen, 2009). For instance, if an item has a low amassed rating yet one individual audit rates the item very, a consumer will scrutinize the believability of this message.

\section{c. Recommendation Consistency}

Recommendation consistency refers to the gradation to which an existing eWOM recommendation is in line with other recommendations about the same product or service experience (Cheung, Luo, Sia, \& Chen, 2009). Reviews about an item or administration are generally composed of more than one commentator yet introduced to consumers together. Subsequently, consumers can undoubtedly get assessments from various clients and analyze the consistency between these online interchanges (Cheung, Luo, Sia, \& Chen, 2009).

\section{Anthology of the Previous Study}

\section{a. Word of Mouth to Electronic Word of Mouth}

Consumers are presented to an incredible number of notices over a wide range of media. Truth be told, consumers can achieve data concerning brands, items, and administrations even by utilizing their cell phones (Shrestha, 2016). As data has improved over the great number of promotions, settling on a choice has turned out to be increasingly trying for customers. This is the reason WOM is well-considered as being a standout amongst the most beneficial data hotspots for customers since it contains previous purchasers' considerations and encounters about brands and their items or services (Arndt, 1967). Previous research found that consumers' sureness is based on previous consumers' opinions as well as understandings more than advertisements of marketers (Sen \& Lerman, 2007). The advertisements begin to lose their capacity on buyers because of reliability issues (Ullah \& Hussain, 2015). On the off chance that the links amongst the sender as well as the beneficiary of the data are durable, the validity of the data will be sufficiently high for the collector to have confidence in that the dealer is dependable (Brown \& Reingen, 1987). On the other hand, WOM has amplified a new dimension due to mutual usage of the Internet. The Internet has streamlined WOM communications by provided that ever- 
increasing space for consumers to share personal opinions as well as experiences (Erkan, 2014). This new type of swap over data has been called eWOM (Hennig-Thurau, Gwinner, Walsh, \& Gremler, 2004). The blogs, consumer review websites, discussion forums, shopping websites and, most recently, social media websites are the example of numerous, unlike online platforms that let eWOM communications amongst consumers (Cheung \& Thadani, 2012).

\section{b. Word of Mouth}

In the communication field, WOM has dependably been reflected as a basic promoting device. As WOM correspondences essentially happen among collectors and senders, the connection between them is one of the principal factors which impact the aftereffects of WOM. Strong connections among beneficiaries and senders increment the specialist of WOM (Bansal \& Voyer, 2000). Besides this factor, there are a few more additional features which regulate the influence of WOM. Consumer buying behaviour is becoming more observant with what they buy (Lange \& Elliot, 2012). Researchers furthermore pull thoughtfulness to the prominence of the level of information which the WOM source (sender) has (Bansal \& Voyer, 2000). WOM sources could either be individuals or stages; however, their information's dimension is critical. If the beneficiaries feel that they are getting qualified data, they can be induced effectively. As such, the dimension of learning impacts the unwavering quality of the WOM source plus, contingent upon the dependability and the WOM will influence the shoppers' purchase intentions (Brown \& Reingen, 1987). Additionally, the purpose of transmitters for provided that information is another serious factor in WOM (Romani, 2006). WOM can be progressively powerful when the collector truly needs to gain proficiency with the data to diminish his or her dangers (Naz, 2014). Purchasers can find exact data that satisfy their very own needs while they are finding out about other shoppers' encounters. It is thus that WOM is persuasive on customers (Taghizadeh, Taghipourian, \& Khazaei, 2013). Thusly, like some other promoting idea, a wide range of WOM have their points of interest and detriments.

\section{c. Advantages and Disadvantages of Word of Mouth}

Bearing in mind the fact that WOM contains actual reviews as well as authentic details about services also products, it is among the most precious sources that consumers can make use of to make greater decisions (Balter \& Butman, 2005). A standout amongst the hugest components which make WOM data progressively sound is that it is made by different shoppers rather than advertisers. People gather concerning information and opinions about the product from people before purchasing (Attia et al., 2012). WOM is additionally profitable for advertisers as promoting messages can rapidly be passed on among purchasers with no costs (Trusov, Bucklin, \& Pauwels, 2009). All things considered, WOM is additionally disadvantageous for organizations in a significant number of ways. As an example, WOM may be disadvantageous to those organizations when destructive comments are shared by disillusioned consumers. This, thusly, could lead individuals to keep away from the items, administrations, brands, and organizations which are being spoken to in a negative light. WOM can't be completely controlled because of its intrinsic structure (Nyilasy, 2006). WOM occurs in a day by day discussions of purchasers. Thus, any erroneous or misjudged data can likewise be spread throughout these discussions. It can even transform into tremendous issues before the impedance of organizations. 


\section{d. Electronic Word of Mouth}

The Internet has transformed as well as improved the way individuals convey. This improvement has brought a crisp, pivotal point of view to WOM, alongside the new name which is the electronic word of mouth or eWOM. The eWOM has been described as 'any constructive or pessimistic articulation made by conceivable, authentic, or past clients about an item or organization, which is made real to a huge number of individuals and establishments employing the Internet' (Hennig-Thurau, Gwinner, Walsh, \& Gremler, 2004). It is also known as "online word of mouth" besides the term "electronic word of mouth". The eWOM can be as one for the customer produced and advertiser created, much the same as the old-fashioned WOM. While the data on the Internet is habitually given by advertisers utilizing organization produced sites, online networks empower individuals to impart their insights with others by making media content as images, recordings or else writings. Web journals, shopper survey sites, talk discussions, shopping sites, and online networking sites are largely divergent sorts of eWOM platforms.

\section{e. Advantages and Disadvantages of Electronic Word of Mouth}

The emerging usage of the Internet has added and added to the development of eWOM. Through technology, primarily the Internet, WOM communication methodologies have become faster and easier (Trusov, Bucklin, \& Pauwels, 2009). The main benefit is that the Internet has enhanced the capacity of WOM (Chatterjee, 2001). Individuals are presently ready to get extra details about the services and items that they are hoping to buy. Additionally, the Internet makes accessible an appropriate stage for advertisers and customers to speak with each other. Nonetheless, the eWOM owned two increasingly basic highlights which can be the two favourable circumstances and weaknesses for advertisers. In the first place, eWOM can contact an enormous spectator for communication can be handed on to thousands or even a great many consumers over the Internet. Second, any eWOM message can be spread in a short-lived timeframe. These two highlights propose incredible open doors for advertisers. Negative remarks, be that as it may, can correspondingly spread quickly among an immense number of shoppers too in such cases, the eWOM can be harming to the image of organizations. Although eWOM oversees an opportunity for advertisers to pursue shoppers' thoughts and interfere if fundamental, the effects of eWOM are still difficult to control, in the same way just like the example of conventional WOM.

\section{f. Difference between Word of Mouth and Electronic Word of Mouth}

In the aforementioned section, it has been checked that WOM and eWOM have a few focal points and weaknesses; in any case, as far as correlation, a few highlights of WOM empower make it more invaluable than eWOM, though different highlights of eWOM cause it to appear to be more noteworthy. Conventional WOM information can touch countless receivers since it permits through a series of consumers (Lau \& Ng, 2001). A successful product sharing could be affected by positive WOM and lack of negative WOM (McGriff, 2012). In the online situation, nevertheless, eWOM can drawn-out quicker among an amount numbers, or some of the time even a great many customers. The way that the Internet makes the spreading of eWOM data colossally quicker is the most noticeable contrast among WOM and eWOM. Besides, eWOM oversee outwardly bolstered data for buyers. Individuals can utilize media content, for example, pictures 
or recordings, while discussing items and administrations to help their conclusions and encounters. In the disconnected case, occasionally verbal interchanges don't enable individuals to consider the data being imparted; by the by, eWOM makes it simpler for consumers. Besides, WOM and eWOM are additionally not alike as far as following their impact. Because of its characteristic structure, following WOM is estimated to be exceptionally testing.

\section{g. The Credibility of Electronic Word of Mouth}

A critical beginning time in the data to induce procedure is the individual's judgment of the believability of data, which decides how much the beneficiary investigations from just as embraces the got data (Wathen \& Burkell, 2002). Consequently, if individuals believe that the data received is valid, they will have more sureness to embrace eWOM data and use it to settle on buy choices. Numerous studies demonstrate the connection between data believability and the selection of the data. Distinguishing that numerous online cooperation occurs between individuals who have no previous relationship, it is critical to think about how these trades are measured and evaluated as "reliable" or trustworthy. Be that as it may, it is additionally relying upon the inspirations to peruse the audit; purchasers will utilize various ways of information processing.

\section{h. Social Media}

Social media networking sites have transformed the way individuals speak with each other. Online networking has been well-characterized as Internet-based administrations which make surroundings which individuals can assemble their profiles and systems while in the meantime enabling them to get to others' close to home profiles and systems (Boyd \& Ellison, 2007). One more description that was offered as being a group of Internet-based applications which permit for the formation and interchange of user-generated content (Kaplan \& Haenlein, 2012). Social media websites have to turn out to be very general in modern years. Multitudes of users have joined on these kinds of communication medium into their day-to-day lives (Okazaki, 2009). The users of social media sites, for example, Facebook, Twitter and Instagram are not just from a similar home nation that the organization is perceived in yet, also originate from all around the globe. Because of the mounting mindfulness of Internet clients, the quantity of online life sites is yet expanding. Also, these sites lead clients to invest more energy with them. In this rationale, internet-based life is prominent among organizations just as people.

\section{i. Word of Mouth, Electronic Word of Mouth and Social Media}

The Internet has eased eWOM communication over a variability of mediums. On the other hand, between social media and other eWOM platforms, there is one major difference. Previously, eWOM only happened in the middle of people who did not recognize one another the introduction of social media websites. Users were chatting with "strangers" (i.e. anonymous people) on the Internet in other words. For this reason, it was difficult for understanding the reliability of comment. Social media has brought with it a new, revolutionary perspective in that it allows eWOM to take place amongst people who at present already know each other although eWOM continues among anonymous people through online reviews. Regarding services, products and brands with their friends and acquaintances, consumers have found a great chance for conveying and discussing their opinions as well as experiences. This is the reason why social 
media websites are well-thought-out as the unquestionably suitable mediums for eWOM. Also, the unrecognizability matter has been fixed since people are more expected to use social media accounts with their real names rather than nicknames. Conveying eWOM via web-based networking media locales, consequently, might be more compelling on customers' buy aims than the eWOM imparted on other online stages.

\section{j. Electronic Word of Mouth and Other Online Platforms}

The Internet has been giving extraordinary chances to buyers to examine their assessments with others since its earliest days. Toward the start of the Internet time, online exchange discussions urged shoppers to discuss everything. After some time, but these gatherings turned out to be increasingly specific and apportioned distinctly with detailed issues. Individuals began composing their very own considerations, encounters, diaries and remarks on their online journals which, thus, were presented to the commitments of the individuals who read it. Although these sites were not fabricated just for discussions associated with items, administrations, or brands, analysts have noticed that half of all bloggers give brand-related data at any rate once every week (Chu \& Kamal, 2008). Later, purchaser survey sites, which are different cases of online stages whereupon eWOM is exchanged, were made, then again, to rouse individuals for the express motivation behind trading their insight and encounters about items and administrations. The data picked up by buyers on these sites is when all is said in done apparently as increasingly solid and important since they are created by different clients rather than advertisers.

\section{THEORY GUIDING THE STUDY}

The continuous development and advancement in technology makes the choice to choose on matters of approval as well as refusal a dilemma, specifically in the ICT interrelated applications (Marangunic \& Granic, 2015). Created on this, out of wholly the models, numerous models and theories have been developed to shed more light on the actual and effective use of technology plus, the Technology Acceptance Model (TAM) stands out in inspecting concerns affecting users' acceptance of modern technology. The Technology Acceptance Model (TAM) is an enlargement of Ajzen and Fishbein's Theory of Reasoned Action (TRA) which was a theory originated by Fred Davis in 1986 plus since then has gone through more than a few alterations and authentication (Priyanka \& Kumar, 2013). The purpose of this theory is to describe and define the aspects that regulate as well as determine the technology acceptance, to make available for a parsimonious theoretical explanatory model and determine the information technology usage behaviour (Bertrand \& Bouchard, 2008). Several features encourage the usage and acceptance of technology (Teo, 2013). He also counts in the individual dissimilarities, beliefs, social influences, situational influences and attitudes as among the causes that uphold the intention to use technology as well as encourage the capability to agree to take or to reject it. 


\section{Demographic}

Consumers

Age \& Gender

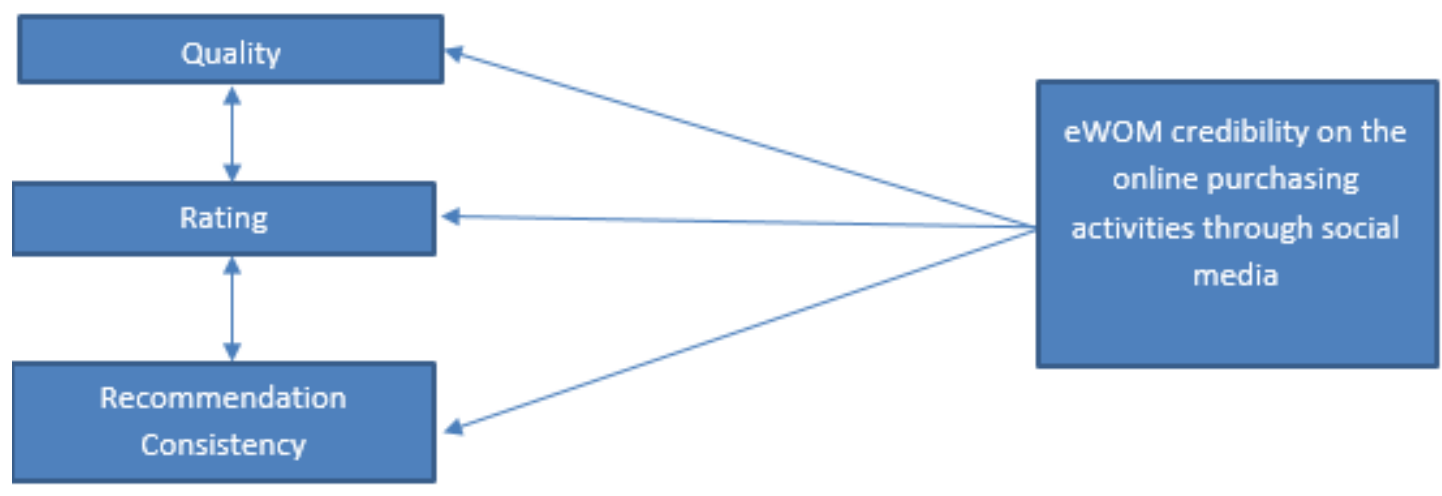

Figure 1: Conceptual Framework

Based on the framework (see Figure 1), the researcher can induce whether the dimensions that have been studied of the eWOM credibility on the online purchasing activities among consumers through social media are accurate or not. According to Ajzen (1991), assertiveness is understood to have an uninterrupted effect on behavioural aim. Assertiveness is a considerable predictor of behavioural intention by numerous researchers. The researcher settled that assertiveness which comes from people towards the acquiescence replicate frame of mind, which are a favour as well as disfavour towards the compliance conduct.

\section{METHODOLOGY}

The design of this research is a quantitative method. The area of this study will be conducted in the central province of Peninsular Malaysia which situated in Kuala Lumpur and Selangor. The selection of the central region is due to the high inclination of the respondents with favours to react with the variables listed in this study and has high potentials to be amongst the mutual users of electronic word of mouth as well as social media. A survey is the method of data collection for this research, which used the questionnaire that has been distributed to the respondents involved by the researcher. In this study, the total sample size is 260 respondents. The researcher prepared the questionnaires according to the research objectives and questions to the respondents. There will be 30 respondents who will contribute to the pilot test and therefore there are 260 respondents that are being involved for the data analysis purpose.

The most appropriate sampling method that is used is non-probability sampling in this study. This sampling does not select their population in a scientifically random way and consequently, non-random samples will produce samples which are not demonstrating the population itself. It means that the possibility to get the oversimplification from them is partial. 
Additionally, the researcher chooses to use quota sampling and the overall numbers of various categories for every single sample is immovable in the non-probability sampling. Then, the sampling procedure is functional in which those accessible respondents will be approached to answer the questionnaires. Data analysis summarize the collected data, which then be interpreted using analytical and logical reasoning to determine patterns, relationship or trends.

\section{RESULTS AND DISCUSSION}

\section{Demographic Profile}

a. Age and Gender

Table 1: Proportion of age and gender of respondents

\begin{tabular}{lccccc}
\hline Gender & Age & Below 30 & Above 30 & Frequency & Percentage (\%) \\
\hline Male & 65 & 65 & 130 & 50.0 \\
Female & 65 & 65 & 130 & 50.0 \\
\hline
\end{tabular}

The table shows the demographic details based on the 260 respondents $(n=260)$. All the questionnaires were distributed to the consumers randomly, who have experienced online purchasing activities through social media. The percentage of the respondents between male and female are equal, which is $50 \%$ for both genders according to this survey. The researcher has divided the category into two ranges of age which are below 30 and above 30 as for the age of respondents. Referring to the survey, the percentage is equal for both categories, $50 \%$ each.

Research Objective 1: To explore the dimensions of electronic word-of-mouth (eWOM) credibility on online purchasing activities among consumers through social media.

\section{b. Exploratory Factor Analysis for Dimensions of eWOM}

Table 1 showed the validity data resulted from the exploratory factor analysis. Based on the results, the Kaiser-Meyer-Olkin (KMO) sampling adequacy is 0.896 which indicate adequate as the value must be 0.6 and above. The significant value of Chi-Square with (df) 435 should be less than 0.05 . Thus, the results for factor analysis showed a significant value of $0.000(p<0.05)$ in this study. The variables created from this analysis are known as latent variables which will be used in the next analysis. Based on the findings, it can be observed that the quality, rating and recommendation consistency were among the dimensions of eWOM credibility on the online purchasing activities among consumers through social media. These three dimensions had gone thru the reliability and normality test, as well as the process of the goodness of measure. From the researcher opinion, all these three dimensions are the most noticeable and prominent features which will give effect on the consumers' decision making. The consumers especially those who were considered as millennial were taking the online purchasing activities as something important in their daily lives. 
Table 2: Outcomes for Exploratory Factor Analysis (EFA) of Dimensions of eWOM

\begin{tabular}{|c|c|c|c|c|}
\hline \multirow[t]{2}{*}{ No } & \multirow[t]{2}{*}{ Items } & \multicolumn{3}{|c|}{ Factor Loadings } \\
\hline & & F1 & F2 & F3 \\
\hline \multicolumn{5}{|c|}{ PART B: DIMENSIONS OF eWOM (QUALITY) } \\
\hline 1. & $\begin{array}{l}\text { D8 Can easily get opinions from different users and } \\
\text { compare the recommendation consistency on the social } \\
\text { media }\end{array}$ & 0.725 & & \\
\hline 2. & D7 Like looking for advice before shopping & 0.702 & & \\
\hline 3. & $\begin{array}{l}\text { D10 Others' advice is important for my purchasing } \\
\text { activities }\end{array}$ & 0.688 & & \\
\hline 4. & $\begin{array}{l}\text { D3 Believe that online reviews are a credible } \\
\text { information source }\end{array}$ & 0.684 & & \\
\hline 5. & $\begin{array}{l}\text { D1 Read online comments and reviews about products } \\
\text { or services that interested in }\end{array}$ & 0.681 & & \\
\hline 6. & $\begin{array}{l}\text { D4 Believe that online review is an important source of } \\
\text { information }\end{array}$ & 0.673 & & \\
\hline 7. & $\begin{array}{l}\text { D5 Believe that online review is written under the } \\
\text { responsibility }\end{array}$ & 0.664 & & \\
\hline 8. & $\begin{array}{l}\text { C4 Product related information in social media is clear } \\
\text { and true }\end{array}$ & 0.657 & & \\
\hline 9. & $\begin{array}{l}\text { D2 Always trust online reviews which are in line with } \\
\text { other recommendations written by other consumers }\end{array}$ & 0.647 & & \\
\hline & $\begin{array}{l}\text { D9 Will feel confused about the recommendation is not } \\
\text { in line with the majority of other messages about the } \\
\text { same product or service }\end{array}$ & 0.640 & & \\
\hline 11. & D6 Rely on online reviews when purchasing a product & 0.639 & & \\
\hline & $\begin{array}{l}\text { C5 The ratings presented on the website are helpful for } \\
\text { my decision making when buying online }\end{array}$ & 0.627 & & \\
\hline \multicolumn{5}{|c|}{ PART C: DIMENSIONS OF eWOM (RATING) } \\
\hline 1. & $\begin{array}{l}\text { B7 Rely on the users' quality reviews on the same } \\
\text { purchase intention on social media }\end{array}$ & & 0.805 & \\
\hline 2. & $\begin{array}{l}\text { B10 Feel that the information given by others are } \\
\text { accurate and can be trusted }\end{array}$ & & 0.799 & \\
\hline 3. & $\begin{array}{l}\text { B8 Believe that the product quality reviews on the } \\
\text { Internet are neutral }\end{array}$ & & 0.798 & \\
\hline 4. & $\begin{array}{l}\text { B9 Confident in the recommendation from an } \\
\text { influencer, and will be more likely to purchase the } \\
\text { product }\end{array}$ & & 0.778 & \\
\hline 5. & B6 People are knowledgeable & & 0.765 & \\
\hline 6. & B5 People are persuasive & & 0.692 & \\
\hline 7. & $\begin{array}{l}\text { C10 Marketing products by the help of social media is } \\
\text { attractive }\end{array}$ & & 0.620 & \\
\hline 8. & $\begin{array}{l}\text { C8 Always look into other online consumers' ratings } \\
\text { before purchasing a product }\end{array}$ & & 0.608 & \\
\hline & $\begin{array}{l}\text { C7 Marketing with social media will be the future of } \\
\text { marketing especially when the rating is high }\end{array}$ & & 0.603 & \\
\hline & $\begin{array}{l}\text { C9 Popularity of the website that presents the ratings } \\
\text { and reviews affect the purchase decision }\end{array}$ & & 0.590 & \\
\hline & $\begin{array}{l}\text { C6 Believe that the product ratings on the internet are } \\
\text { neutral }\end{array}$ & & 0.557 & \\
\hline
\end{tabular}




\section{PART D: DIMENSION OF EWOM (RECOMMENDATION CONSISTENCY)}

1. B2 The reviews that relevance and appropriate will attract attention

2. B1 The quality reviews presented on the website are helpful for decision making

3. B3 Will be worried about the decision if don't read the quality reviews

4. B4 Reliability of the site that presents the reviews affect

0.657 the purchase decision

KMO Measure of Sampling Adequacy

Df

Research Objective 2: To measure the relationship between the dimensions of electronic wordof-mouth (eWOM) credibility on the online purchasing activities among consumers through social media are related to each other.

\section{c. Data of Correlation}

Table 2 below showed the result of correlation analysis which point out a positive relationship between the dimensions (independent variables) with Pearson $r$ value $0.603,0.504,0.625$ and $p$ value 0.000 . Thus, it can be indicating that there is a significant relationship between all the dimensions of eWOM credibility on the online purchasing activities among consumers through social media. All dimensions that were being explored in this research were correlated, connected and dependable to each other. From the researcher's standpoint, the dimensions of eWOM credibility on the online purchasing activities among consumers through social media have a relationship between each other despite their functions. These dimensions were important for the consumers especially during the process of buying through the online medium. People may look onto the quality of the eWOM that available for particular products or services, as well as for the rating and recommendation consistency that obtainable and can be easily accessible.

Table 3: Outcomes for Correlation Test of Dimensions of eWOM

\begin{tabular}{llccc}
\hline Variable & & $\begin{array}{c}\text { Quality } \\
\text { (IV) }\end{array}$ & $\begin{array}{c}\text { Rating } \\
\text { (IV) }\end{array}$ & $\begin{array}{c}\text { Recommendation } \\
\text { Consistency (IV) }\end{array}$ \\
\hline Quality (IV) & Pearson Correlation & 1 & $0.603^{* *}$ & $0.504^{* *}$ \\
& Sig. (2-tailed) & & 0.000 & 0.000 \\
Rating (IV) & Pearson Correlation & $0.603^{* *}$ & 1 & $0.625^{* *}$ \\
& Sig. (2-tailed) & 0.000 & & 0.000 \\
Recommendation Consistency (IV) & Pearson Correlation & $0.504^{* *}$ & $0.625^{* *}$ & 1 \\
& Sig. (2-tailed) & 0.000 & 0.000 & \\
\hline
\end{tabular}

**. Correlation is significant at the 0.01 level (2-tailed). 
Research Objective 3: To determine the differences in the dimensions of electronic word-ofmouth (eWOM) credibility on the online purchasing activities among consumers through social media between consumers of different age and gender.

\section{e. $\quad$ Data of Independent Sample T-Test}

To determine whether there is statistical evidence that the associated population means are significantly different, the independent sample t-test is conducted to compare the means of two independent groups. The conditions were then separated into below 30 and above 30 for age, and male and female for gender.

For the quality which is the dimension of the eWOM credibility, there is no significant difference in the scores for age below $30(M=45.3615, S D=8.17351)$ and age above 30 $(\mathrm{M}=43.6231, \mathrm{SD}=9.20420)$ conditions; $\mathrm{t}(258)=1.610, \mathrm{p}=0.109$. For the rating which is also the dimension of the eWOM credibility, there is no significant difference in the scores for age below $30(\mathrm{M}=40.7462, \mathrm{SD}=7.95853)$ and age above $30(\mathrm{M}=43.6231, \mathrm{SD}=9.20420)$ conditions; $\mathrm{t}(258)=1.610, \mathrm{p}=0.109$ because the $\mathrm{p}$-value is more than 0.05 . And next, for the recommendation consistency which is also the dimension of the eWOM credibility, there is a significant difference in the scores for age below $30(M=14.4692, S D=3.72544)$ and age above $30(M=13.4231$, $S D=3.83752$ ) conditions; $t(258)=2.230, p=0.027$. Moving to the next condition which is gender, for the quality which is the dimension of the eWOM credibility, there is a significant different in the scores for male $(M=42.5231, S D=8.06198)$ and female $(M=46.4615, S D=8.95740)$ conditions; $\mathrm{t}(258)=-3.726, p=0.000$ because the $p$-value is less than 0.05 . Next, for the rating which is the dimension of the eWOM credibility, there is a significant difference in the scores for male $(M=36.6154, S D=8.68786)$ and female $(M=39.2462, S D=8.79664)$ conditions; $t(258)=-2.426, p=$ 0.016 . Last but not least, for the recommendation consistency which is the dimension of the eWOM credibility, there is a significant difference in the scores for male $(M=13.0077$, $\mathrm{SD}=3.52949)$ and female $(\mathrm{M}=14.8846, \mathrm{SD}=3.86323)$ conditions; $\mathrm{t}(258)=-4.090, \mathrm{p}=0.000$.

These results suggest that the age and gender do have effects on the dimensions of eWOM credibility. When the age and gender differences, the perception and reaction towards the credibility is different as well. All the conditions tend to have different choices and their preferences while purchasing the items or any services through social media. Specifically, when consumers are making decisions on online purchasing activities, they will consider the dimensions that had been mentioned before.

Table 4: Group Statistics of Age

\begin{tabular}{lccccc}
\hline & Age & N & Mean & Std. Deviation & Std. Error Mean \\
\hline Quality & Below 30 & 130 & 45.3615 & 8.17351 & .71686 \\
& Above 30 & 130 & 43.6231 & 9.20420 & .80726 \\
Rating & Below 30 & 130 & 40.7462 & 7.95853 & .69801 \\
& Above 30 & 130 & 35.1154 & 8.77685 & .76978 \\
Recommendation & Below 30 & 130 & 14.4692 & 3.72544 & .32674 \\
Consistency & & & & & \\
& Above 30 & 130 & 13.4231 & 3.83752 & .33657 \\
\hline
\end{tabular}




\begin{tabular}{|c|c|c|c|c|c|c|c|c|c|c|c|c|}
\hline \multirow[t]{3}{*}{$\mathbf{F}$} & & \multicolumn{2}{|c|}{$\begin{array}{l}\text { Levene's Test } \\
\text { for Equality of } \\
\text { Variances }\end{array}$} & \multicolumn{7}{|c|}{ t-test for Equality of Means } & & \\
\hline & & \multirow[t]{2}{*}{ Sig. } & \multirow[t]{2}{*}{$\mathbf{t}$} & \multirow{2}{*}{\multicolumn{2}{|c|}{ Df }} & \multirow{2}{*}{\multicolumn{2}{|c|}{$\begin{array}{l}\text { Sig. (2- } \\
\text { tailed) }\end{array}$}} & \multirow{2}{*}{\multicolumn{2}{|c|}{$\begin{array}{l}\text { Mean } \\
\text { Difference }\end{array}$}} & \multirow[t]{2}{*}{$\begin{array}{l}\text { Std. Error } \\
\text { Difference }\end{array}$} & \multicolumn{2}{|c|}{$\begin{array}{l}95 \% \text { Confidence Interval } \\
\text { of the Difference }\end{array}$} \\
\hline & & & & & & & & & & & Lower & Upper \\
\hline \multirow[t]{2}{*}{ Quality } & Equal variances assumed & .280 & 1.610 & 258 & & 109 & & & 3846 & 1.07961 & -.38752 & 3.86444 \\
\hline & $\begin{array}{l}\text { Equal variances not } \\
\text { assumed }\end{array}$ & & 1.610 & 254.4 & & 109 & & & 3846 & 1.07961 & -.38766 & 3.86458 \\
\hline \multirow[t]{2}{*}{ Rating } & Equal variances assumed & .045 & 5.419 & 258 & & .000 & & & 3077 & 1.03912 & 3.58452 & 7.67701 \\
\hline & $\begin{array}{l}\text { Equal variances not } \\
\text { assumed }\end{array}$ & & 5.419 & 255.5 & & .000 & & & 3077 & 1.03912 & 3.58443 & 7.67711 \\
\hline \multirow{2}{*}{$\begin{array}{l}\text { Recommendation } \\
\text { Consistency }\end{array}$} & Equal variance assumed & .565 & 2.230 & \multirow{2}{*}{\multicolumn{2}{|c|}{$\begin{array}{l}258 \\
257.774\end{array}$}} & \multirow{2}{*}{\multicolumn{2}{|c|}{$\begin{array}{l}.027 \\
.027\end{array}$}} & & .46909 & .12243 & 1.96988 \\
\hline & $\begin{array}{l}\text { Equal variances not } \\
\text { assumed }\end{array}$ & & 2.230 & & & & & \multicolumn{2}{|c|}{1.04615} & .46909 & .12242 & 1.96988 \\
\hline \multicolumn{13}{|c|}{ Table 6: Result of Independent T-Test } \\
\hline \multirow[t]{3}{*}{$\mathbf{F}$} & & & \multicolumn{2}{|c|}{$\begin{array}{l}\text { Levene's Test } \\
\text { for Equality of } \\
\text { Variances }\end{array}$} & \multicolumn{5}{|c|}{ t-test for Equality of Means } & & & \\
\hline & & & \multirow[t]{2}{*}{ Sig. } & \multirow[t]{2}{*}{$\mathbf{t}$} & \multirow{2}{*}{\multicolumn{2}{|c|}{ df }} & \multirow{2}{*}{\multicolumn{2}{|c|}{$\begin{array}{l}\text { Sig. (2- } \\
\text { tailed) }\end{array}$}} & \multirow[t]{2}{*}{$\begin{array}{l}\text { Mean } \\
\text { Difference }\end{array}$} & \multirow[t]{2}{*}{$\begin{array}{l}\text { Std. Error } \\
\text { Difference }\end{array}$} & \multicolumn{2}{|c|}{$\begin{array}{l}95 \% \text { Confidence } \\
\text { Interval of the } \\
\text { Difference }\end{array}$} \\
\hline & & & & & & & & & & & Lower & Upper \\
\hline \multirow[t]{2}{*}{ Quality } & Equal variances assumed & & .325 & -3.726 & 25 & & .00 & & -3.93846 & 1.05696 & -6.01982 & -1.85710 \\
\hline & Equal variances not assumed & & & -3.726 & & 190 & .00 & & -3.93846 & 1.05696 & -6.01993 & -1.85699 \\
\hline \multirow[t]{2}{*}{ Rating } & Equal variances assumed & & .925 & -2.426 & 25 & & .0 & & -2.63077 & 1.08436 & -4.76610 & -.49544 \\
\hline & Equal variances not assumed & & & -2.426 & & 960 & .0 & & -2.63077 & 1.08436 & -4.76610 & -.49544 \\
\hline Recommendation & Equal variance assumed & & .534 & -4.090 & 25 & & .00 & & -1.87692 & .45894 & -2.78068 & -.97317 \\
\hline Consistency & Equal variances not assumed & & & -4.090 & 25 & 922 & .00 & & -1.87692 & .45894 & -2.78071 & -.97313 \\
\hline
\end{tabular}


Table 7: Group Statistics of Gender

\begin{tabular}{lccccc}
\hline & Age & N & Mean & Std. Deviation & Std. Error Mean \\
\hline Quality & Male & 130 & 42.5231 & 8.06198 & .70708 \\
& Female & 130 & 46.4615 & 8.95740 & .78562 \\
Rating & Male & 130 & 36.6154 & 8.68786 & .76198 \\
& Female & 130 & 39.2462 & 8.79664 & .77152 \\
Recommendation & Male & 130 & 13.0077 & 3.52949 & .30956 \\
Consistency & Female & 130 & 14.8846 & 3.86323 & .33883 \\
\hline
\end{tabular}

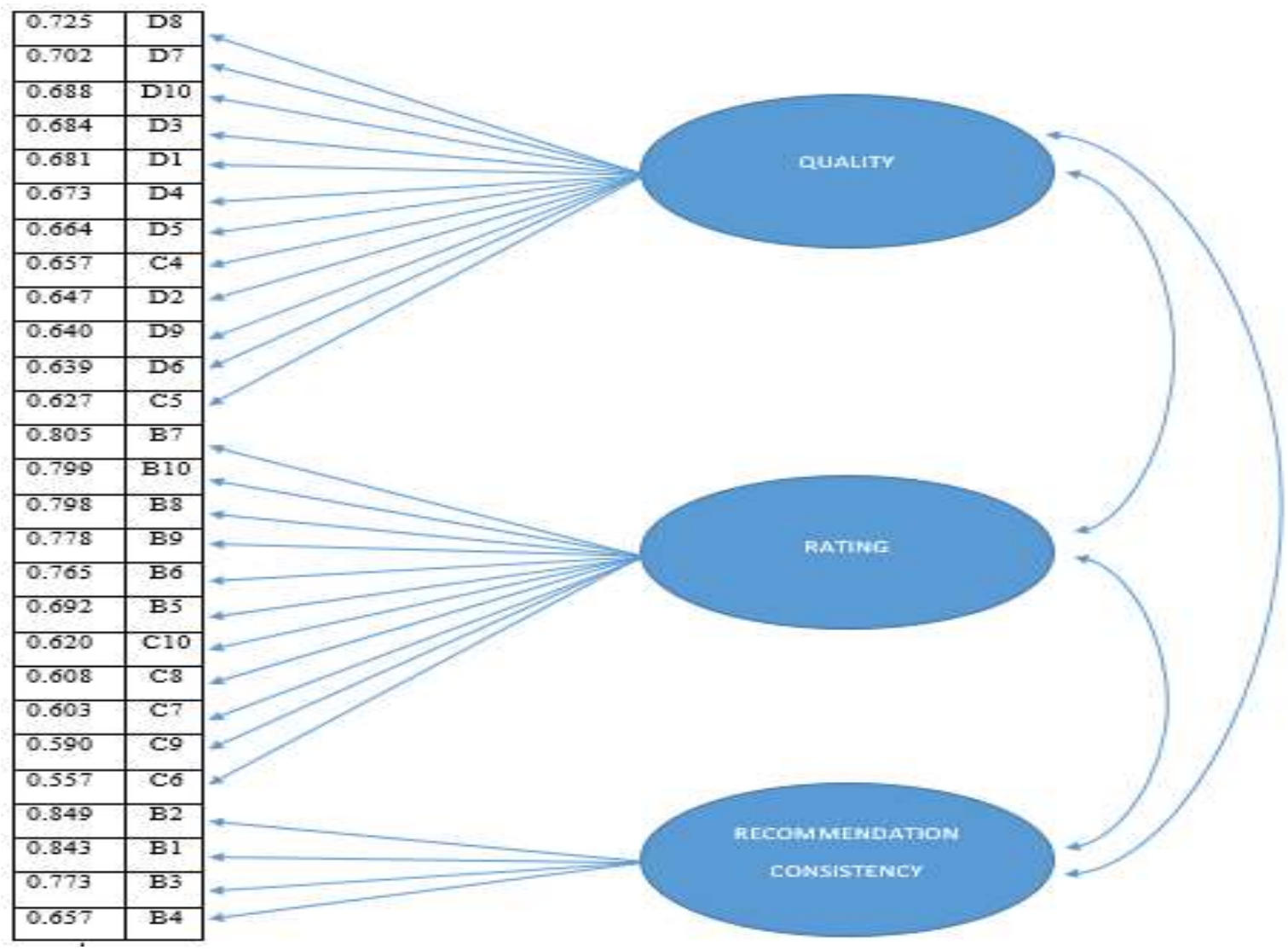

Figure 2: Measurement Model of eWOM Credibility on the Online Purchasing Activities among Consumers through Social Media based on Quality, Rating and Recommendation Consistency

As can be seen in the above framework, it is the new model of the measurement model of eWOM that was resulted in the outcomes of this research. This research had created another measurement model for eWOM which can be used by other researchers in future research. Having said this, it should be distinguished that measurement itself is a very authoritative treatment as it describes goals as well as guides action. All the items that were accurately organized based on the results, can be utilized and might help other researchers to achieve deeper and more profound findings in the next related research.

\section{CONCLUSION}

This research study has analyzed and discussed on the dimensions of eWOM credibility which quality, rating and recommendation consistency significantly underpinning the online are purchasing activities among consumers through social media. From the traditional word of mouth to the electronic word of mouth, this kind of communication was helpful especially in the related area such as business and marketing. In the modern era, the improvement of social media 
has conveyed one newer angle to electronic word of mouth (eWOM) through permitting consumers to speak with their existing systems or the existing networks. Via social media, despite dissimilar stages, clients can exchange their experiences as well as thoughts about items or services with well-known individuals which might be get away to individuals who they know. Understandably, the message on the reviews which considered as one of the medium of eWOM itself is acute for information credibility. The message should be on the inside consistent, reliable and undoubtedly presented. Other than that, the consumers' characteristics are also important where consumers who are already amenable to a message will be more likely to view the information as credible. The researcher has confidence in doing this research where all the research questions had been answered well and the research objectives of this research had achieved as well.

\section{ACKNOWLEDGEMENT}

First and foremost, the researcher would like to show appreciation to Allah for His mercy upon her. She would like to express gratitude for the coaching, guidance and input from her respected supervisor, Dr. Mohammad bin Yaacob who had supervised her for all the directions that ensure the completion of this research. Not to forget, Dr. Wan Hartini Wan Zainodin who also had provided invaluable guidance throughout this journey. The researcher feels very blessed to have many delightful friends with endless encouragement especially to Amirah Mahirah, Siti Nuraein, Wan Nur Fazrin, Siti Fairus, Nursyamimie and Naim Razaleigh. Also, the researcher claimed this as a miracle that happened to her towards the end of the writing journey which she cannot begin to express her unfailing gratitude and love to Muhammad Firdaus Mohd Razi, who has supported her endlessly throughout this process as well as constantly encouraging when the tasks seemed arduous and insurmountable. Apart of that, she would like to acknowledge the endless support, patience and encouragement provided by her family especially both of her parents, Haji Baharuddin Abdul Rashid and Hajah Khadijah Mokhtar for their love, care and prayers, also for all the support and assistance while she was surviving with the writing until the finishing line. Finally, thank you Allah for making it all possible.

\section{BIODATA}

Nor Amira binti Baharuddin had completed Master of Mass Communication at UiTM Shah Alam and currently working in the academic field. Email: namirabaharuddin@gmail.com

Mohammad bin Yaacob had completed Doctor of Philosophy (Mass Communication) at UiTM and currently working in the academic field as a Senior Lecturer with an experience of more than 30 years. Email: mbyzuria@gmail.com 


\section{REFERENCES}

Arndt, J. (1967). Role of product related conversations in the diffusion of a new product. Journal of Marketing Research, 4(3), 291-295.

Attia, A. M., Aziz, N., \& Friedman, B. A. (2012). The impact of social networks on behavioural change: A conceptual framework. World Review of Business Research, 2, 91-108.

Balter, D., \& Butman, J. (2005). Grapevine: The new art of word-of-mouth marketing. London: Penguin Group.

Bansal, H. S., \& Voyer, P. A. (2000). Word-of-mouth processes within a services purchase decision context. Journal of Service Research, 3(2), 166-177.

Bertrand, M., \& Bouchard, S. (2008). Applying the technology acceptance model to VR with people who are favourable to its use. Journal of Cyber Therapy \& Rehabilitation, 1(2).

Boyd, D. M., \& Ellison, N. B. (2007). Social network sites: Definition, history and scholarship. Journal of Computer-Mediated Communication, 13(1), 210-230.

Brown, J., \& Reingen, P. (1987). Social ties and word-of-mouth referral behavior. Journal of Consumer Research, 14(3), 350-362.

Chatterjee, P. (2001). Online reviews: Do consumers use them?. Advances in Consumer Research, 129-134.

Cheung, C., \& Thadani, D. (2012). The impact of electronic word-of-mouth communication: A literature analysis and integrative model. Desicion Support Systems, 461-470.

Cheung, M. Y., Luo, C., Sia, C. L., \& Chen, H. (2009). Credibility of electronic word-of-mouth: Informational and normative determinants of online consumer recommendations. International Journal of Electronic Commerce, 13(4), 9-38.

Chu, S.-C., \& Kamal, S. (2008). The effect of perceived blogger credibility and argument quality on message elaboration and brand attitudes. Journal of Interactive Advertising, 26-37.

Doh, S.-J., \& Hwang, J.-S. (2009). How consumers evaluate eWOM (Electronic Word-of-Mouth) messages. Cyber Psychology \& Behavior.

Eccleston, D., \& Griseri, L. (2008). How does web 2.0 stretch traditional influencing patterns. International Journal of Market Research, 50(5), 591-161.

Eisner, E. W. (1991). The enlightened eye: Qualitative inquiry and the enhancement of educational practice. New York: Macmillan Publishing Company.

Engel, J., Blackwell, R., \& Kegerreis, R. (1969). How information is used to adopt an innovation. Journal of Advertising Research, 9(4), 3-8.

Erkan, I. (2014). Vine: Do you miss it? Electronic word of mouth on the social networking site, Vine. International Journal of Business and Information, 9(4), 461-473.

Gogoi, B. (2013). Study of antecedents of purchase intention and its effect on brand loyalty of private label brand of apparel. International Journal of Sales \& Marketing, 3(2), 73-86.

Heale, R., \& Twycross, A. (2015). Validity and reliability in quantitative studies. Ontario, Canada: group.bmj.com.

Hennig-Thurau, T., Gwinner, K., Walsh, G., \& Gremler, D. (2004). Electronic word-of-mouth via consumer-opinion platforms: What motivates consumers to articulate themselves on

the Internet?. Journal of Interactive Marketing, 18(1), 38-52.

Hoe, J., Dastane, O., \& Selvaraj, K. (2018). Predicting consumer perception and its impact on purchase intention for residential property market. Journal of Technology Management and Business, 5(2), 59-77.

Iduozee, E. (2015). The credibility of online consumer reviews. Tempere, Finland: University of Tampere. 
Kaplan, A. M., \& Haenlein, M. (2012). Social media: Back to the roots and back to the future. Journal of Systems and Information, 101-104.

Keller. (2007). Unleashing the power of word of mouth: Creating brand advocacy to drive growth. Journal of Advertising Research, 47(4), 448-452.

Keller, E., \& Libai, B. (2009). A holistic approach to the measurement of WOM. ESOMAR Worldwide Media Measurement Conference. Stockholm.

Kline, R. B. (2005). Methodology in the social sciences: Principles and practice of structural equation modelling (2nd ed.). New York: Guilford Press.

Lange-Faria, W., \& Elliot, S. (2012). Understanding the role of social media in destination marketing. Tourismos. An International Multidisciplinary Journal of Tourism, 7(1).

Lau, G. T., \& Ng, S. (2001). Individual and situational factors influencing negative word-ofmouth behaviour. Canadian Journal of Administrative Sciences, 18(3), 163-178.

Marangunic, N., \& Granic, A. (2015). Technology acceptance model: A literature review from 1986 to 2013. Universal Access Information Society, 14, 81-95.

McGriff, J. A. (2012). A conceptual topic in marketing management: The emerging need for protecting and managing brand equity: The case of online consumer brand boycotts. International Management Review, 8(1), 49-54.

Mirabi, V., Akbariyeh, H., \& Tahmasebifard, H. (2015). A study of factors affecting on customers purchases intention. Journal of Multidisciplinary Engineering Science and Technology (JMEST), 2(1).

Mohsin, M. (2019, March 7). 10 social media statistics you need to know in 2019. Oberlo. Retrieved from https://my.oberlo.com/blog/social-media-marketing-statistics

Naz, F. (2014). Word of mouth and its impact on marketing. International Journal of Scientific and Research Publications, 4(1), 1-4.

Nunnally, J. C. (1978). Psychometric theory (2nd ed.). New York: McGraw-Hill.

Nyilasy, G. (2006). Word of mouth: What we really know - and what we don't. London, UK: Butterworth-Heinemann.

Okazaki, S. (2009). Social influence model and electronic word of mouth. International Journal of Advertising, 28(3), 439-472.

Patton, M. Q. (2001). Qualitative research \& evaluation methods. Thousand Oaks: Sage.

Potter, W. J. (2005). Media literacy (3rd. Ed.). Thousand Oaks, CA: Sage.

Priyanka, S., \& Kumar, A. (2013). Understanding the evolution of technology acceptance model. International Journal of Advance Research in Computer Science and Management Studies, 1(6), 144-148.

Robertson, T. S., \& Kassarjian, H. H. (1991). Handbook of consumer behavior. NJ: Prentice Hall.

Romani, S. (2006). Price misleading advertising: Effects on trustworthiness toward the source of information and willingness to buy. Journal of Product \& Brand Management, 130138.

Sekaran, U. (2006). Research method for business: A skill building approach. Hoboken, NJ: John Wiley \& Sons.

Sekaran, U. (2006). Research methods for business: A skill building approach. Hoboken, NJ: John Wiley \& Sons.

Sekaran, U., \& Bougie, R. (2013). Research methods for business: A skill-building approach (6th ed.). New York: Wiley. 
Sen, S., \& Lerman, D. (2007). Why are you telling me this? An examination into negative consumer reviews on the Web. Journal of Interactive Marketing, 21(4), 76-94.

Shah, S., Aziz, J., Jaffari, A., Waris, S., Ejaz, W., Fatima, M., \& Sherazi, S. (2012). The impact of brands on consumer purchase intentions. Asian Journal of Business Management, 4(2), 105-110.

Shrestha, S. (2016). Influencing factors on consumer buying behaviour of smart phones. Turku, Finland: Turku University of Applied Sciences.

Taghizadeh, H., Taghipourian, M., \& Khazaei, A. (2013). The effect of customer satisfaction on word of mouth communication. Research Journal of Applied Sciences, Engineering and Technology, 2569-2575.

Teo, T. (2013). A comparison of non-tested models in explaining teachers' intention to use technology. British Journal of Educational Technology, 44(3).

Trusov, M., Bucklin, R., \& Pauwels, K. (2009). Effects of word-of-mouth versus traditional marketing: Findings from an internet social networking site. Journal of Marketing, 90102.

Tsao, W.-C., \& Hsieh, M.-T. (2012). Exploring how relationship quality influences positive eWOM: The importance of customer commitment. Journal of Total Quality Management \& Business Excellence, 23(7-8), 821-835.

Ullah, N., \& Hussain, M. (2015). Impact of unethical advertising, misleading information or deceptive advertising on customer purchasing intention with mediating effect of word of mouth: Case of Pakistan. International Journal of Innovation and Economic Development, 1(4), 49-69.

Wathen, N. C., \& Burkell, J. (2002). Believe it or not: Factors influencing credibility on the web. Journal of the American Society for Information Science and Technology, 53(2), 134144.

Winter, G. (2000). A comparative discussion of the notion of 'validity' in qualitative and quantitative research. The Qualitative Report, 4(3), 1-14. Retrieved from https://nsuworks.nova.edu/tqr/vol4/iss3/4 